Article

\title{
Blue Growth Development in the Mediterranean Sea: Quantifying the Benefits of an Integrated Wave Energy Converter at Genoa Harbour
}

\author{
George Lavidas ${ }^{1, *(\mathbb{D})}$, Francesco De Leo ${ }^{2, *(\mathbb{D})}$ and Giovanni Besio ${ }^{2, *(\mathbb{C})}$ \\ 1 Department of Civil Engineering and Geosciences, Delft University of Technology, Stevinweg 1, \\ 2628 CN Delft, The Netherlands \\ 2 Department of Civil, Chemical and Environmental Engineering, University of Genoa, Via Montallegro 1, \\ 16145 Genoa, Italy \\ * Correspondence: glavidas@gmail.com or g.lavidas@tudelft.nl (G.L.); francesco.deleo@edu.unige.it (F.D.L.); \\ giovanni.besio@unige.it (G.B.)
}

Received: 10 July 2020; Accepted: 6 August 2020; Published: 14 August 2020

\begin{abstract}
Coastal resilience is often achieved by traditional civil engineering projects, such as dikes and breakwaters. However, given the pressing nature of Climate Change, integrating energy converters in "classical" structures can enhance innovation, and help in pursuing decarbonisation targets. In this work, we present an alternative for integrating a wave energy converter at a vertical wall breakwater, following past successful projects. Our approach is based on a high spatio-temporal wave dataset to properly quantify expected energy production, but also focus on the hours for which other time-dependent renewables cannot produce, i.e., solar. Our analysis evaluates the power performance and assesses the economic parameters and viability of the proposed installation. Our integrated solution shares the main capital with the breakwater and can produce from $390 \mathrm{MWh}-2300 \mathrm{MWh}$ /year, displacing more than $1760 \mathrm{Tn}$ of $\mathrm{CO}_{2}$ annually. In addition to power generated, we estimated the payback period for most cases being approximately 10-15 years, but when accounting avoided oil $\mathrm{CO}_{2}$ emissions, the installation is highly attractive with payback in less than 9 years, with favourable financing indicating 3.4 years.
\end{abstract}

Keywords: wave energy; levelised cost of energy; payback period; genoa harbour

\section{Introduction}

The European Green New Deal and the Strategic Energy Technology Plan (SET-Plan) are some of the initiatives employed to address Climate Change and become a leader in the decarbonisation [1-3]. Such initiatives, while ambitious, are vital for the mitigation of Climate Change impacts and the transformation of several sectors; in this framework, key component will be the coupling and beneficial integration with renewable energies. To enhance the applicability and importance of clean developments, pivotal focus must be given to synergic solutions that have as a primary focus the use of indigenous renewable energy resources.

Coastal regions in the Mediterranean are at an immediate risk of Climate Change, sea level rise driving increases in extreme events, potential flooding and erosion [4-7]. This can create severe problems for coastal populated areas, cities and the security of operations for crucial sectors such as harbors. Indeed, the Mediterranean shores are densely populated and about $20 \%$ of the world's seaborn commerce passes through the Mediterranean sea [8]. The increasing pressure at Mediterranean coastlines requires taking adaptation measures and rethinking coastal infrastructure design, embedding policies that pursue sectoral decarbonization and carbon neutral operations. These have been particularly developed over the past years, with leaders California, Shenzhen [9] 
and the Port of Rotterdam [10]. Most of the proposed solutions include photovoltaic and onshore wind as sources of renewable electricity. However, wave energy production remains one of the most overlooked and under-utilized resource, with high synergies at coastal locations for power production, coastal protection and even production of green hydrogen [11].

The Italian energy mix is heavily dominated by oil and natural gas (see Figure 1), with net energy consumption $\approx 315$ TWh per year $[12,13]$. Italy has translated the aims for Blue Growth and further development of ocean energies into tangible targets, reducing greenhouse gas emissions by $40 \%$ (compared with 1990) and 30\% of gross energy consumption from renewables by 2030 [14]. With a future perspective, the Italian NECP has set ambitious goals for the development and regional (within the Mediterranean) cooperation for wave energy development. Wave energy is part of the Blue Growth agenda, and part of the technologies are represented in the SET-Plan.

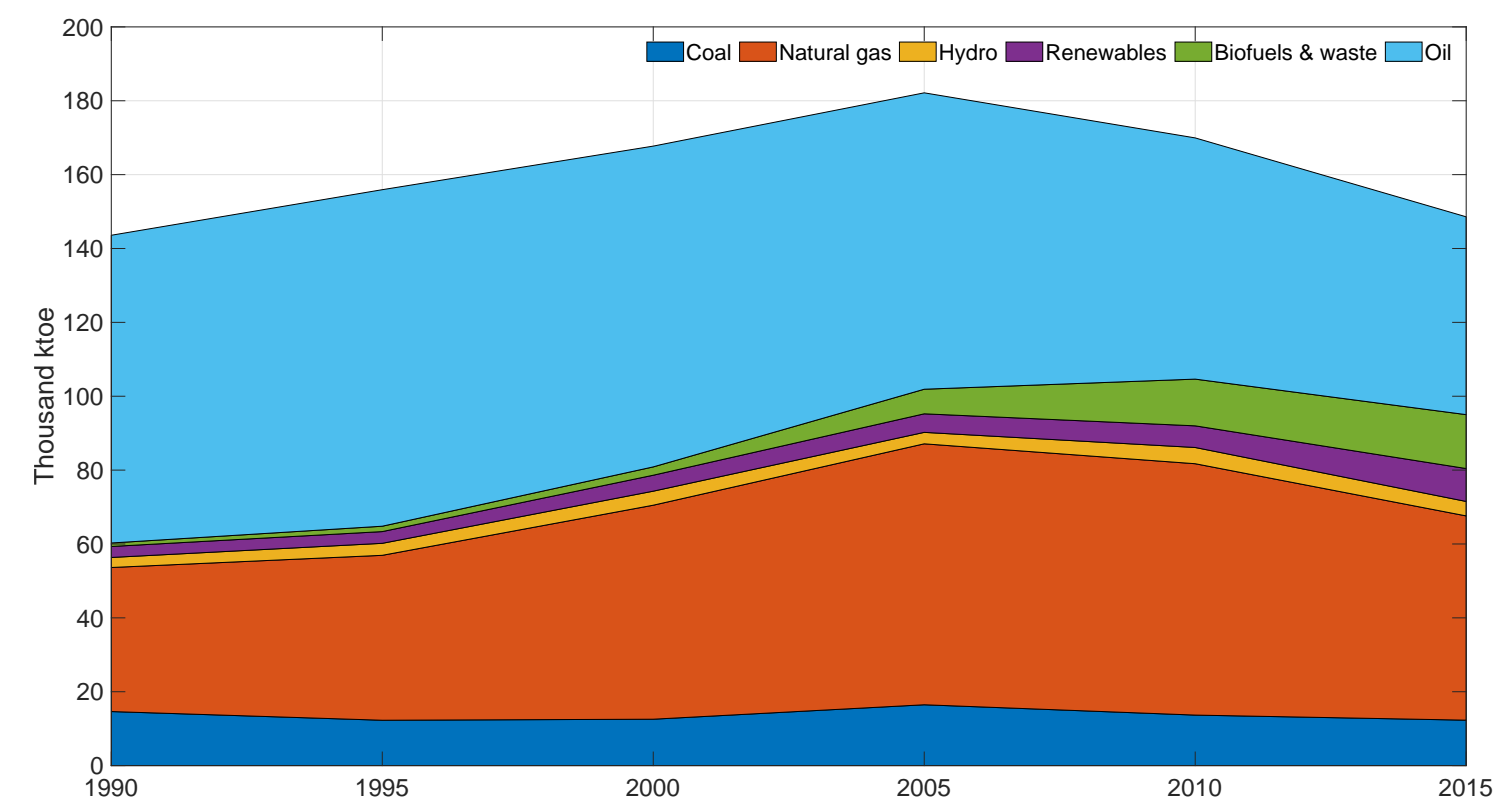

Figure 1. Energy mix of the primary energy supply, own analysis based on data from the International Energy Agency (IEA) [13].

There are numerous wave energy converters (WEC) that can be selected for wave resource exploitation $[15,16]$. These can be classified into several categories according to principle of operation, and/or power-take off, and/or deployment depth. Most commonly, though, WECs are distinguished by their deployment applicability and are separated into shoreline, nearshore and deep water devices [17]. Knowledge of metocean conditions is vital to ensure the optimisation of any type of power take off for WEC, whether that is a linear generator [18] or the optimisation of hydrodynamic characteristic for increased efficiency of an Oscillating Water Column [19].

Vicinanza et al. [20] refer to "hybrid maritime structures" as innovative integration techniques to combined WEC into existing or planned coastal structures with the purpose of the structure as a whole to maintain protection from metocean harsh events [21]. It is, however, a logical evolution for someone to think that the integration of WECs into coastal structures will also benefit other sectorial developments. Indeed, a consortium [22] has been formed to accelerate the coupling of ocean energies with the harbours, assisting in Blue Growth targets but also directly addressing the International Maritime Organisation (IMO) targets for sectoral decarbonisation [23], with a focus primarily given to regions at the Atlantic coasts.

This study contributes with detailed examination of the tangible benefits of a possible integrated breakwater OWC within the new dike at the Genoa harbor, see Figure 2. The port of Genoa, comprised of the Genoa and Savona hubs, is one of the busiest port in Italy and Central Europe [24,25]. The port encompasses several specialised terminals that can handle different types of cargo, 
from technological equipment to fresh produce. Operative versatility also means that energy requirements have to be constantly met, especially in the case of sensitive produce. In addition, the large traffic has increased requirements in cold ironing (i.e., berthing) for parked ships [26]. It currently handles $\approx 2.6$ million TEUS, and this amount is expected to increase in the next future. As such, in 2018, the Port Authority launched a project for enlarging the port capacity, implying the building of a new dike farther seaward with respect to the actual existing one [27]. In addition, the Port Authority has set an ambitious plan for energy efficiency and production by renewable sources $[25,28]$.

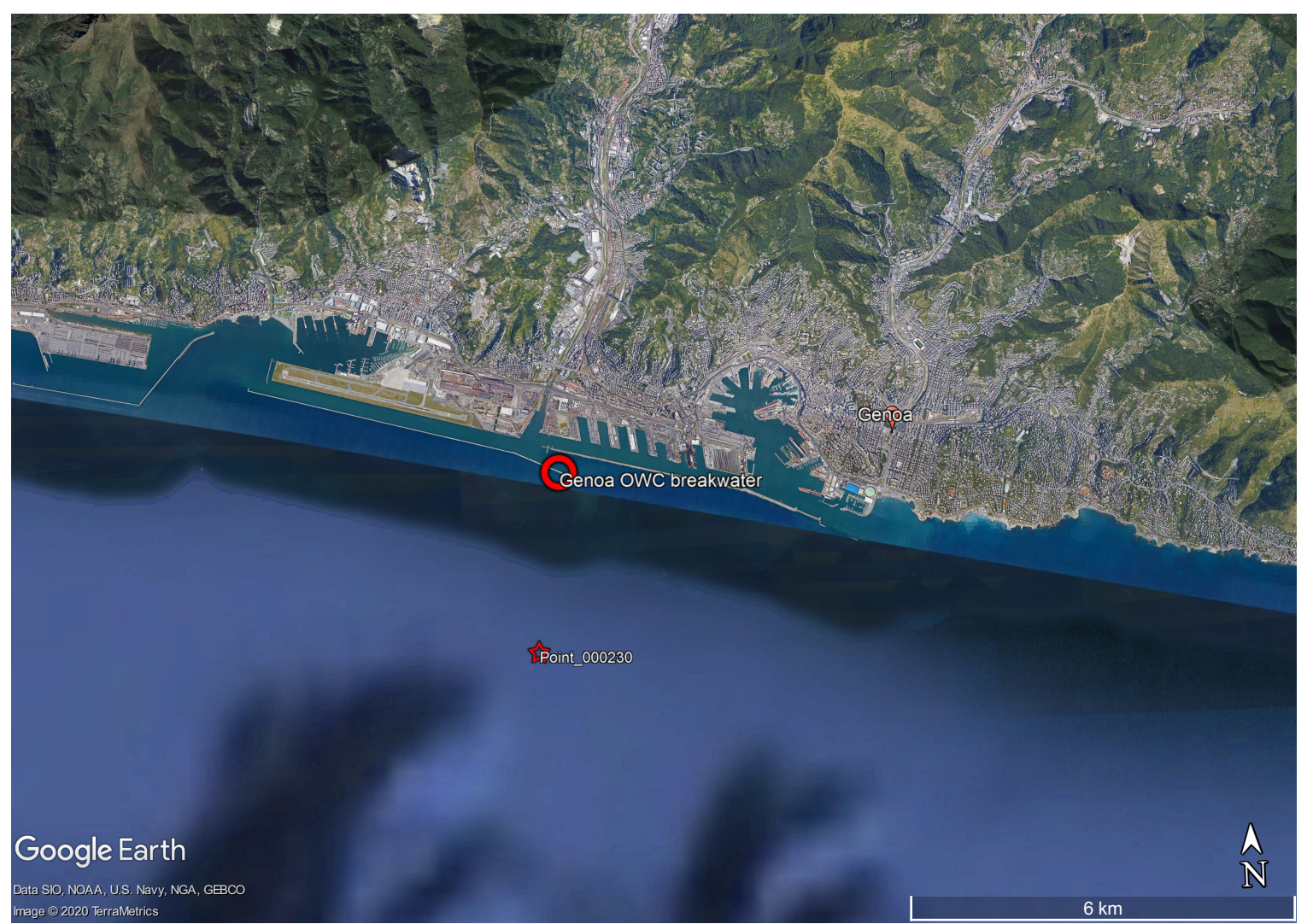

Figure 2. Close-up at area of interest, hindcast node 000230 and the node where local wave data were carried out are depicted.

In view of the above, we assess the techno-economic potential and avoided emissions of a possible WEC installation at the Genoa breakwater. Through combining multi-nesting with suitable numerical wave model allowing for estimating realistic Levelised Cost of Electricity (LCoE), and the payback period (PBP) for the configuration. Moreover, the study goes beyond that and also estimates the off-day hours contribution profile. This is highly important as it can help immensely in the decarbonization efforts of Genoa Port, mitigating some of other renewable energies (i.e., photovoltaic) intermittency.

The paper is structured as follows. Section 2 introduces data and methods employed in the work, while Results are drawn and discussed in Sections 3 and 4, respectively. Conclusions and final remarks are finally reported in Section 5.

\section{Material and Methods}

There is a wide variety of WECs that can be used, however, not all are suitable for mild environments as their peak production is related to coupled probabilities of significant wave height $\left(H_{m 0}\right)$ and peak wave period $\left(T_{\text {peak }}\right)$. Our focus here is the integration and hybridization opportunities offered by an OWC converter to a harbour expansion. While OWC design has been installed and is operative (i.e., Mitruku) [29], their power matrix is not available and, as mentioned in Naty et al. [30], this can hinder development of studies. For the potential OWC, we have adopted the power matrix of 
an OWC and obtained the capacity factor (CF) based on a 40 years hindcast analysis, as indicated by other studies [31,32].

For the detailed characterization of the local wave climate, we took advantage of the hindcast data provided by the Department of Civil, Chemical and Environmental Engineering of the University of Genoa [33,34]. The data are defined on a hourly base over the period 1979-2018 in the node 000230 at a depth of about $650 \mathrm{~m}$ (http:/ / www3.dicca.unige.it/meteocean/hindcast.html), and were therefore subsequently downscaled in front of the dike with Simulating WAves Nearshore model (SWAN, [35,36]). The use of SWAN allows for higher fidelity simulation near shallow water, where oceanic models often use approximation for shallow water dynamics, thus allowing for properly accounting for the large depth variations the regional bathymetry is characterized by (see Figure 2). Using a neashore model driven by validated boundaries takes advantage of faster computation time and higher shallow water accuracy with similar model chains [37-40]. Our boundary conditions are extracted by a validated and calibrated model, and considering the small fetch, validity of the underlying data benefits by the shallow water source terms of SWAN. The figure shows a close-up of the investigated area, highlighting the input and output wave data nodes, with the latter further used for the estimation of annual energy production.

In terms of Capital Expenditure (CapEx), a range has been considered to make the analysis more useful and scalable. Naty et al. [30] suggested an OWC represents approximately $10 \%$ of the total cost of the harbour expansion structure. Contestabile et al. [41] provided sensitivity costs for an integrated breakwater energy solution from $\approx 560,000 €$ to $\approx 2,700,000 €$ and installed capacity from $500 \mathrm{~kW}$ to 2 MW, albeit a different concept with pico turbines was considered, but similar in terms of integration and thus expected costs as it was adapted to a breakwater.

The CapEx of this analysis is based on the official procurement documents for the total cost of the suggested Genoa breakwater [42]. The planned Genoa breakwater total length is about $5 \mathrm{~km}$, with estimated cost $800,000,000 €$ and expected lifetime 50 years. This corresponds to $\approx 160,000 € / \mathrm{m}$ for the construction. OWC costs are thus a function of $€ / \mathrm{m}$ and total installed capacity in Megawatts $(\mathrm{MW})$, this is represented by $\approx 1.3$ Million $€ / \mathrm{MW}$, with OWC length and value adapted by Babarit et al. [43].

Discount rate for the installation was considered at $7 \%$, with maintenance and operation accounting for 3\% of CapEx; typically, renewable energy project have discount rates from $5-15 \%$ with the highest representing a high risk investment. The integrated OWC breakwater approach can reduce risks as the structure does not require major overhaul/modification. In addition, it is common for large civil beneficial project to be co-financed Public-Private Partnerships (PPP) reducing their level of danger, and can also be given preferential "social discount rates" from 1-5\% [44]. The analysis estimates LCoE using the discounted method, and considering a lifetime for the OWC of 40 years, with a repowering of the electrical power take of the facility at year $20\left(\right.$ RePower $\left._{20}\right)$, valued at $20 \%$ of the initial CapEx [45]. For breakwater integrated WECs, the majority of expenditure is civil engineering works.

The economic evaluation and feasibility of the breakwater OWC concept for the Genoa port, is strengthened by the realistic CF obtained through the 40 year metocean dataset for energy analysis. CapEx of the installation includes all works and covers all elements of the OWC; however, a range has been given to the costs as it has sensitivity on the estimation based on location and installed capacity, as shown in Table 1. 
Table 1. Estimated total CapEx for different installed capacities and costs, values include facility re-powering.

\begin{tabular}{ccccc}
\hline \multicolumn{5}{c}{ Total Cost $€ / \mathbf{M W}$} \\
\hline MW & $\mathbf{1 , 5 0 0 , 0 0 0 € / M W}$ & $\mathbf{2 , 0 0 0 , 0 0 0 € / M W}$ & $\mathbf{2 , 5 0 0 , 0 0 0 € / M W ~}$ & $\mathbf{3 , 0 0 0 , 0 0 0 € / M W}$ \\
\hline 0.5 & $900,000 €$ & $1,200,000 €$ & $1,500,000 €$ & $1,800,000 €$ \\
1 & $1,800,000 €$ & $2,400,000 €$ & $3,000,000 €$ & $3,600,000 €$ \\
1.5 & $2,700,000 €$ & $3,600,000 €$ & $4,500,000 €$ & $5,400,000 €$ \\
2 & $3,600,000 €$ & $4,800,000 €$ & $6,000,000 €$ & $7,200,000 €$ \\
2.5 & $4,500,000 €$ & $6,000,000 €$ & $7,500,000 €$ & $9,000,000 €$ \\
3 & $5,400,000 €$ & $7,200,000 €$ & $9,000,000 €$ & $10,800,000 €$ \\
\hline
\end{tabular}

Levelized Cost of Energy or LCoE is an indispensable tool as it provides a level field for technology comparisons; it does not directly dictate the economic viability, see Equation (1). CapEx and maintenance $(\mathrm{OM})$ are costs expressed in Euro $(€)$ discounted at present values (PV). Annual energy production (AEP) is the estimation of energy production by the joint probability distribution of $H_{m 0}$ and $T_{\text {peak }}[31,32,46-48]$. To provide a feasibility estimate, the simple Pay Back Period (PBP) [44] is considered (see Equation (2)), using the guaranteed selling price of electricity $(300 € / \mathrm{MWh})\left(R_{n}\right)$ given by the Italian government [49]. The "viable" PBP period is considered at any value below 20 years.

$$
\begin{gathered}
L C o E=\frac{P V(\text { CapEx })+P V\left(\text { RePower }_{20}\right)+P V(O M)}{P V(A E P)} \\
P B P=\frac{\text { CapEx }+ \text { RePower }}{R_{n}-O M}
\end{gathered}
$$

Finally, avoiding emissions and monetary benefits by increased energy security, and avoiding imports of energy expressed in barrels of oil equivalent (bbl) are estimated according similar studies [50]. The analysis also provides the potential revenue combination of the Emission Trading Scheme (ETS), with a price of $35 € / \mathrm{TnCO}_{2}$. Carbon pricing per Tonne is based on the current prices, though they are expected to increase since $2018 \mathrm{CO}_{2}$ prices have seen dramatic increase from $\approx 5 € /$ allowance ( $\mathrm{Tn}$ ) $\mathrm{CO}_{2}$ (2013 price) to near $25 € / \mathrm{Tn} \mathrm{CO}_{2}$, a fivefold increase, see Figure 3 . Estimates are expecting the barrier of $35 € / \mathrm{Tn} \mathrm{CO}_{2}$ to be exceeded soon, and 2030 future values to be $\geq 60-80 € / \operatorname{Tn} \mathrm{CO}_{2}$.

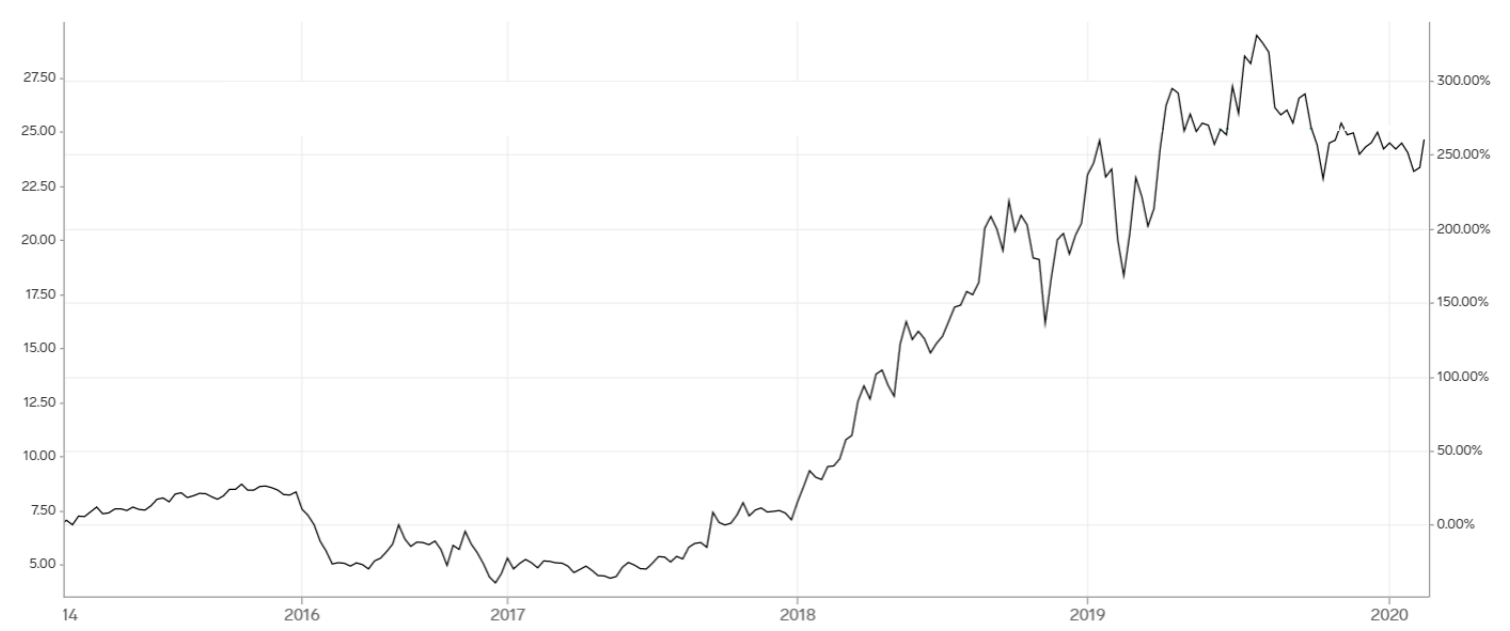

Figure 3. $\mathrm{CO}_{2}$ European Emission Allowances $(€)$, showing the evolution of prices during the last five years [51]. 


\section{Results}

The energy analysis indicates that, through the region, performance and capacity factors are similar, with maximum value $\approx 11.5 \%$. Surrounding the Ports of Genoa, the CF is $\approx 6-11 \%$, with mean value of $\approx 8 \%$. Focusing at the Port of Genoa, the specific location data representing $44^{\circ} 24^{\prime} \mathrm{N} 8^{\circ} 53^{\prime} \mathrm{E}$ were extracted. The analysis utilises 40 years of data allowing for robust energy estimates, considering the effects of Climate variation on the OWC performance. Moreover, the historical wave climate can be assumed to be representative of the future climatology of the area. Indeed, as far as wave parameters are concerned, the investigated location is not characterized by relevant historical trends [52], nor it is expected to be significantly affected by future variations driven by Climate Change [53].

Annual energy performance of the OWC is given at Figure 4, along with the estimated Coefficient of Variation (CoV). At the port of Genoa, the mean value of $\mathrm{CF}$ is $8.85 \%$, the $\mathrm{CoV}$ indicates a small level of variation expected annually, therefore showing little drops in performance. As it can be seen in Figure 4, there seems to be a cyclic maxima performance every three years, followed by a decrease every two years.

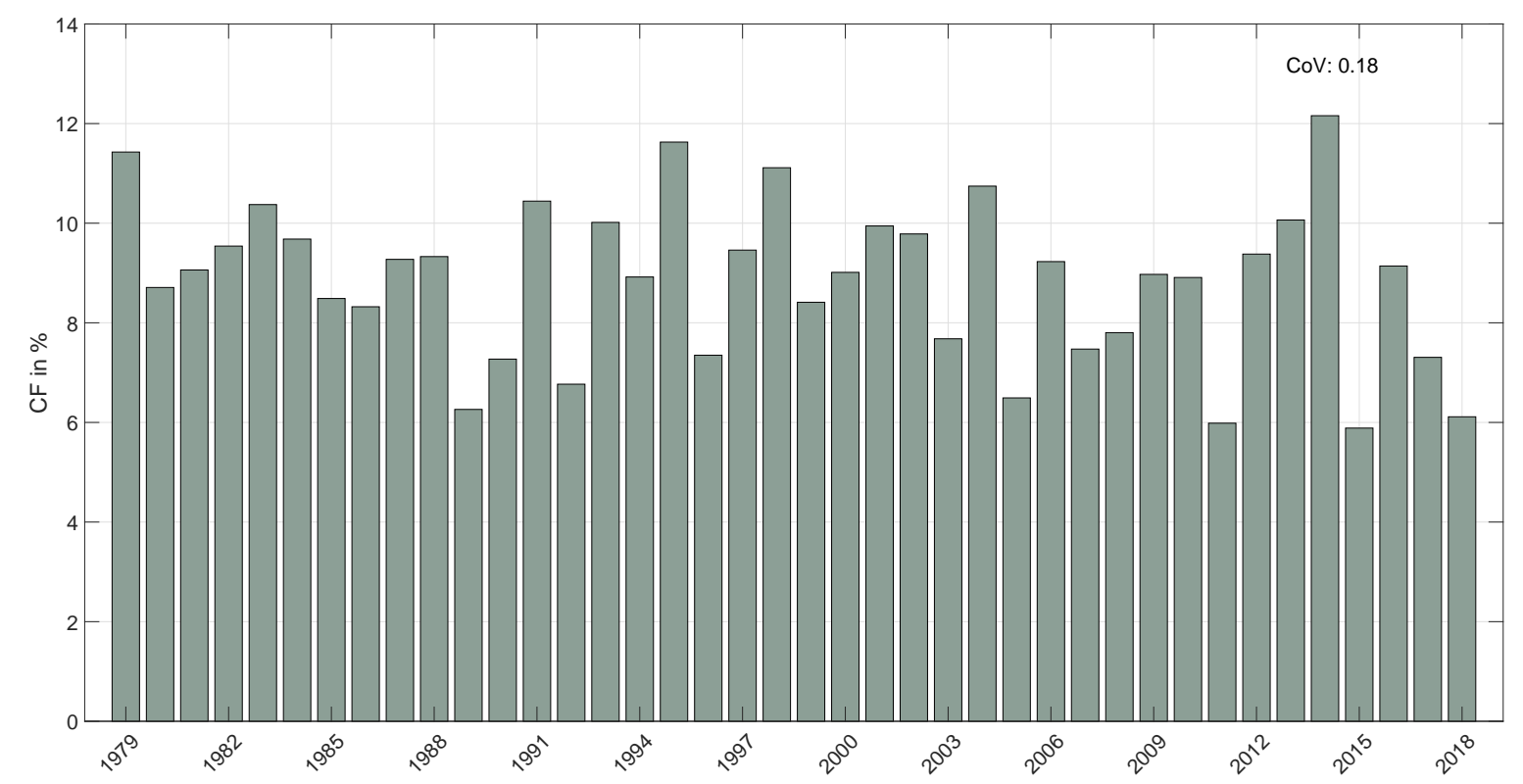

Figure 4. Variation of capacity factor for the location.

LCoE can be used to compare different energy technologies, regardless of their resource origin, expressed in currency per energy produced [54]. There are two main components for LCoE estimations, cost/expenditure and energy production, see Equation (1). LCoE does not indicate the economic viability, but it evaluates the probable aggregated energy cost. The simple payback period (PBP) (see Equation (2)) is used to assess the business feasibility evaluating the time required for the installation to "return" the capital. Avoided emission per fuel type and avoided energy imports are also estimated, and used with the produced electricity to assess additional PBP options that benefit by quantifying the Climate mitigation impacts. The energy estimates and avoided emissions per fuel type, dominant in the Italian energy mix are given in Table 2.

Table 2. Annual energy production and displacement of emissions by dominant fuel types.

\begin{tabular}{ccccccc}
\hline & $\mathbf{0 . 5} \mathbf{M W}$ & $\mathbf{1} \mathbf{M W}$ & $\mathbf{1 . 5} \mathbf{M W}$ & $\mathbf{2} \mathbf{M W}$ & $\mathbf{2 . 5} \mathbf{M W}$ & $\mathbf{3} \mathbf{M W}$ \\
\hline AEP (MWh/year) & 387.55 & 775.11 & 1162.66 & 1550.21 & 1937.77 & 2325.32 \\
Oil avoided Tn $\mathrm{CO}_{2} /$ year & 293.92 & 587.85 & 881.77 & 1175.70 & 1469.62 & 1763.54 \\
NG avoided Tn $\mathrm{CO}_{2} /$ year & 199.52 & 399.05 & 598.57 & 798.10 & 997.62 & 1197.14 \\
\hline
\end{tabular}


Given the fact that one specific device is proposed here, LCoE will be mostly a function of CapEx. As the installed capacity increases, the LCoE sees a reduction. The lowest LCoE $185.80 € / \mathrm{MWh}$ is for $3 \mathrm{MW}$ installed capacity, with a total CapEx 1,500,000€ and maintenance 162,000€/year. The highest LCoE is $627.05 € / \mathrm{MWh}$ when the cost per MW is 3,000,000€, and for a $0.5 \mathrm{MW}$ configuration total costs scale to $10,800,000$ and $324,000 €$ /year maintenance, see Figure 5 .

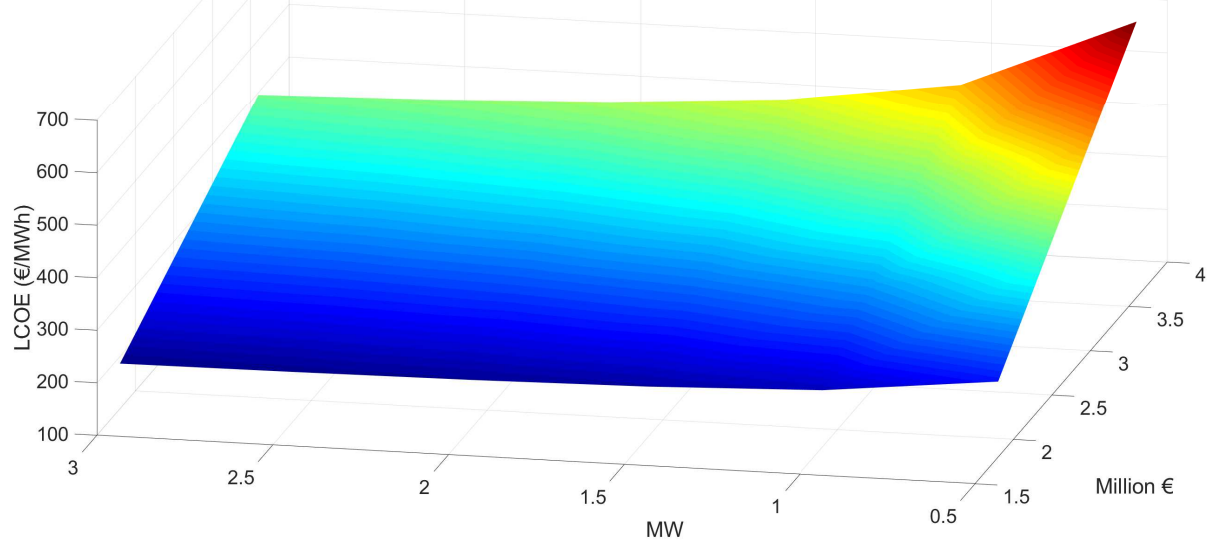

Figure 5. LCoE for breakwater of the OWC with estimations based off the Port of Genoa.

The simple PBP gives more in-depth information concerning the feasibility of the project, accounting only for gross revenue by electricity sold. In this case, even higher capital intensive scenarios are beneficial. In Table 3, coloured cells indicate the intensity in years needed to payback the capital, with green high recovery and red a slow recovery. Even at a LCoE value of $191.61 € / \mathrm{MWh}$ ( $2 \mathrm{MW}$ and CapEx 1,500,000 €/MW), the performance is positive, with 6.72 years necessary to be profitable. However, higher LCoE values i.e., 394.82 (1 MW and CapEx 2,500,000 €/MW), the PBP is marginally out of our limit (i.e., 20 years) with 21 years. CapEx below $2-5$ Million $€ / M W$ values combined with capacities $\geq 1 \mathrm{MW}$ achieve always positive payback, as low as 3.4 years.

Incorporating an OWC also offers significant benefits in offsetting carbon emissions by conventional sources, and hence increasing the sustainability of operation for the Port of Genoa. These values can be from $\approx 300-1763.54 \mathrm{Tn} \mathrm{CO}_{2} /$ year for oil based electricity and $\approx 200-1200 \mathrm{Tn}$ $\mathrm{CO}_{2}$ /year for Natural Gas (NG), see Table 2, effectively reducing the carbon budget and making the Port of Genoa highly competitive and sustainable with regard to its emissions. When additional revenues by avoided $\mathrm{TnCO}_{2}$ are factored in Table 3, high payback times are reduced by $\approx 10-15 \%$. An already "positive" PBP shows only slight improvements, which does alter the economic evaluation for $\leq 2,500,000$ euro/MW, making them marginally profitable at 18.4 and 19.2 years with and avoided emissions from oil and natural gas, respectively. With this added revenue factored, units that cost from 1.5-2 Million $€ / M W$ obtain a an average improvement in PBP 6-10 months and above 2.5 Million improvements on average from $15-24$ months. Capacities $\leq 0.5 \mathrm{MW}$ do not achieve a positive value with the electricity only PBP.

Another under-estimated characteristic is the beneficial mis-match of operation with other renewable energies. This in fact can enhance the utilisation of energy by renewables, whilst minimizing expensive solutions as batteries, which for industrial solution can be as high $\approx 1000 € / \mathrm{MWh}$ (as stand-alone solutions), and from $\approx 280-360 € / \mathrm{MWh}$ (as part of storing electricity by photovoltaics) [55]. Besides the aggregated annual energy performance, the hourly power production was analysed, and a filter was applied to focus only on hours that photovoltaics do not produce (from 6:00 p.m.-8:00 a.m.). The minimum hours operated in this timeframe of non-sunshine, the lower 
value was in 2005 with $5.85 \%$ in total hours, the maximum was $10.72 \%$ in 2000 , with mean power production in such hours representing $8.25 \%$. The density plot (see Figure 6) complements these findings, with the potential distribution being within the range of $7-9 \%$.

Table 3. PBP for different scenarios, quantifying the avoided emissions as added revenue stream for an Genoa optimised OWC.

\begin{tabular}{|c|c|c|c|c|}
\hline & \multicolumn{4}{|c|}{ Total Cost $€ / M W$} \\
\hline & \multicolumn{4}{|c|}{ PBP Electricity Only, for CF: $8.85 \%$} \\
\hline & $1,500,000 € / \mathrm{MW}$ & $2,000,000 € / \mathrm{MW}$ & $2,500,000 € / \mathrm{MW}$ & $3,000,000 € / \mathrm{MW}$ \\
\hline $0.5 \mathrm{MW}$ & 20.2 & 29.9 & 42.1 & 57.8 \\
\hline $1 \mathrm{MW}$ & 10.1 & 15.0 & 21.0 & 28.9 \\
\hline $1.5 \mathrm{MW}$ & 6.7 & 10.0 & 14.0 & 19.3 \\
\hline $2 \mathrm{MW}$ & 5.0 & 7.5 & 10.5 & 14.5 \\
\hline $2.5 \mathrm{MW}$ & 4.0 & 6.0 & 8.4 & 11.6 \\
\hline $3 \mathrm{MW}$ & 3.4 & 5.0 & 7.0 & 9.6 \\
\hline \multicolumn{5}{|c|}{ PBP with Electricity and Avoided Oil Emissions, for CF: $8.85 \%$} \\
\hline $0.5 \mathrm{MW}$ & 18.1 & 26.5 & 36.8 & 49.6 \\
\hline $1 \mathrm{MW}$ & 9.0 & 13.3 & 18.4 & 24.8 \\
\hline $1.5 \mathrm{MW}$ & 6.0 & 8.8 & 12.3 & 16.5 \\
\hline $2 \mathrm{MW}$ & 4.5 & 6.6 & 9.2 & 12.4 \\
\hline $2.5 \mathrm{MW}$ & 3.6 & 5.3 & 7.4 & 9.9 \\
\hline $3 \mathrm{MW}$ & 3.0 & 4.4 & 6.1 & 8.3 \\
\hline \multicolumn{5}{|c|}{ PBP with Electricity and Avoided Natural Gas (NG) Emissions, for CF: $8.85 \%$} \\
\hline $0.5 \mathrm{MW}$ & 18.7 & 27.5 & 38.3 & 52.0 \\
\hline $1 \mathrm{MW}$ & 9.4 & 13.8 & 19.2 & 26.0 \\
\hline $1.5 \mathrm{MW}$ & 6.2 & 9.2 & 12.8 & 17.3 \\
\hline $2 \mathrm{MW}$ & 4.7 & 6.9 & 9.6 & 13.0 \\
\hline $2.5 \mathrm{MW}$ & 3.7 & 5.5 & 7.7 & 10.4 \\
\hline $3 \mathrm{MW}$ & 3.1 & 4.6 & 6.4 & 8.7 \\
\hline
\end{tabular}

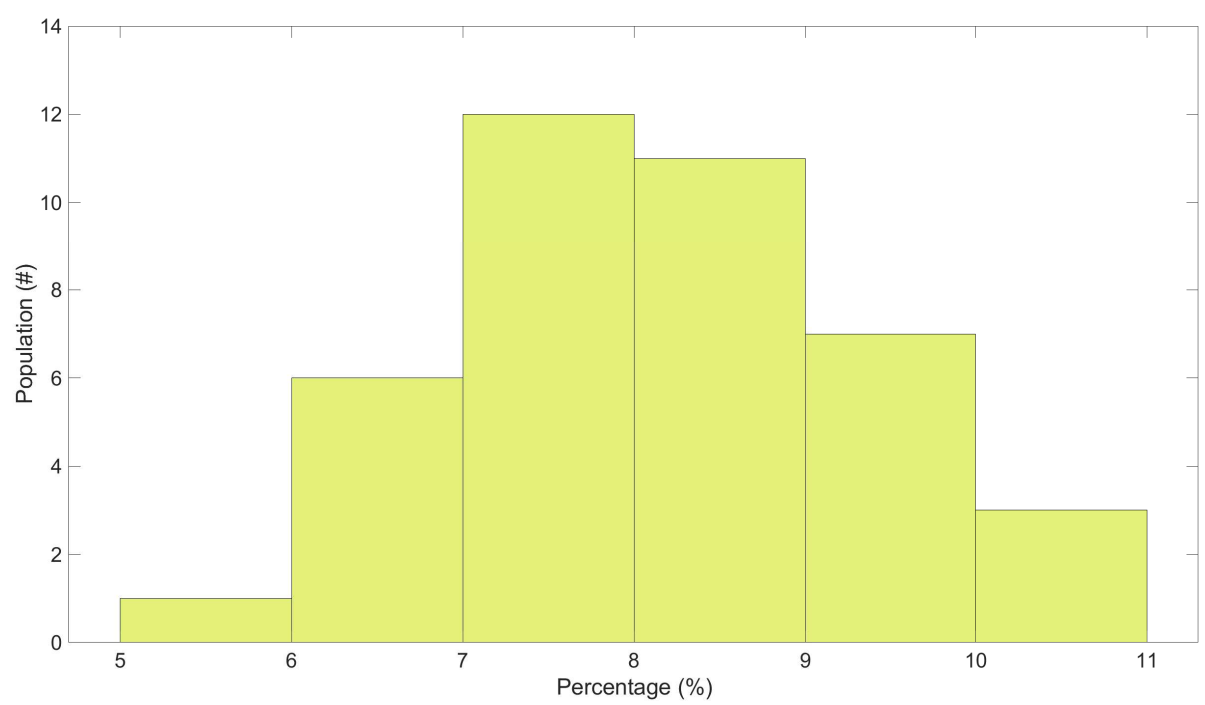

Figure 6. Probability density for the percentage of operative hours between 6:00 p.m.-8:00 a.m.

\section{Discussion}

Given through use of long-term metocean condition, response of the turbines can be tuned to $H_{m 0} \leq 3.5 \mathrm{~m}$. Even with this small configuration change, it is expected that the performance can be 
increased to $40-50 \%$ by adapting the turbine operation to the local conditions [47], usually done by CFD modeling that has shown the improvements that an OWC can attain [56,57]. However, such an effort is outside of the scope for this paper, whose primary focus is to quantify the resource, energy and economic potential.

Indicatively, by adapting the OWC operation to smaller wave heights and higher frequency waves a CF of $15 \%$ is feasible. This in fact reduced the LCoE by $41 \%$ with the highest price being $287.70 € / \mathrm{MWh}$ (presuming 3 million $€ / \mathrm{MW}$ and $0.5 \mathrm{MW}$ installed), while, with a low CapEx $(1,500,000 € / \mathrm{MW}), \mathrm{LCoE}$ prices become highly competitive from $\approx 109.60-123.30 € / \mathrm{MWh}$. As expected, an improvement in the performance also enhances the financial viability. With the adaption potential, increasing expected energy performance the payback period are also significantly reduced. When considering only electricity production as the main revenue stream, the CapEx and installed MW was advised not to exceed 2.5 million $€ / \mathrm{MW}$ and be more than $1 \mathrm{MW}$, in order to achieve positive payback periods below 10 years, see Table 3 . However, the increased performance allows us to consider the solution of smaller installed capacity and even higher CapEx, whilst ensuring that the PBP is achieved in $\leq 10$ years. This allows for a higher threshold couple of CapEx-MW, with viable considerations from 2 million $€ / M W$ and $1 \mathrm{MW}$, with a PBP period exceeding 10 years, an improvement of $47-56 \%$ from the original PBP, see also Table 4.

Table 4. PBP for different scenarios, quantifying the avoided emissions as an added revenue stream for an Genoa optimised OWC, for a adapted WEC with increased performance CF:15\%.

\begin{tabular}{|c|c|c|c|c|}
\hline & \multicolumn{4}{|c|}{ Total Cost €/MW } \\
\hline & \multicolumn{4}{|c|}{ PBP Electricity Only, for CF: $15 \%$} \\
\hline & $1,500,000 € / \mathrm{MW}$ & $2,000,000 € / \mathrm{MW}$ & $2,500,000 € / \mathrm{MW}$ & $3,000,000 € / \mathrm{MW}$ \\
\hline $0.5 \mathrm{MW}$ & 10.6 & 14.9 & 19.7 & 25.2 \\
\hline $1 \mathrm{MW}$ & 5.3 & 7.4 & 9.9 & 12.6 \\
\hline $1.5 \mathrm{MW}$ & 3.5 & 5.0 & 6.6 & 8.4 \\
\hline $2 \mathrm{MW}$ & 2.6 & 3.7 & 4.9 & 6.3 \\
\hline $2.5 \mathrm{MW}$ & 2.1 & 3.0 & 3.9 & 5.0 \\
\hline \multirow[t]{2}{*}{$3 \mathrm{MW}$} & 1.8 & 2.5 & 3.3 & 4.2 \\
\hline & \multicolumn{4}{|c|}{ PBP with Electricity and Avoided Oil Emissions, for CF: $15 \%$} \\
\hline $0.5 \mathrm{MW}$ & 9.6 & 13.4 & 17.7 & 22.4 \\
\hline $1 \mathrm{MW}$ & 4.8 & 6.7 & 8.8 & 11.2 \\
\hline $1.5 \mathrm{MW}$ & 3.2 & 4.5 & 5.9 & 7.5 \\
\hline $2 \mathrm{MW}$ & 2.4 & 3.4 & 4.4 & 5.6 \\
\hline $2.5 \mathrm{MW}$ & 1.9 & 2.7 & 3.5 & 4.5 \\
\hline \multirow[t]{2}{*}{$3 \mathrm{MW}$} & 1.6 & 2.2 & 2.9 & 3.7 \\
\hline & \multicolumn{4}{|c|}{ PBP with Electricity and Avoided Natural Gas (NG) Emissions, for CF: 15\% } \\
\hline $0.5 \mathrm{MW}$ & 9.9 & 13.9 & 18.3 & 23.2 \\
\hline $1 \mathrm{MW}$ & 4.9 & 6.9 & 9.1 & 11.6 \\
\hline $1.5 \mathrm{MW}$ & 3.3 & 4.6 & 6.1 & 7.7 \\
\hline $2 \mathrm{MW}$ & 2.5 & 3.5 & 4.6 & 5.8 \\
\hline $2.5 \mathrm{MW}$ & 2.0 & 2.8 & 3.7 & 4.6 \\
\hline $3 \mathrm{MW}$ & 1.6 & 2.3 & 3.0 & 3.9 \\
\hline
\end{tabular}

Finally, the temporal energy production of the facility, without being optimised, shows that it can produce outside solar production hours. [58]. Furthermore, analysis and multi power coupling will be required to fully analyse the overlapping power production, but the findings suggest reduction in expected storage requirements, which displace conventional fossil fuels effectively.

\section{Conclusions}

The option to have an WEC integrated breakwater at the port of Genoa ensures that the port will protect the area from harsh incoming waves but also contribute towards the port decarbonisation. 
However, in order for the solution to be viable, a first layer analysis has to estimate its profitability. This work uses a long-term high fidelity wave numerical model from 1979-2018, estimating the potential energy production for an integrated OWC at the Port of Genoa.

The primary focus is to provide the Port Authority with renewable energy and offset emissions. It has been shown by Friedrich and Lavidas [58] that multi-generation and high renewables share is expected have positive benefits, like the reduction dispatchable generation without requiring higher reserve capacity. The interest of several sectors for decarbonization has been increased, and it is obvious that multi-generation will be an important asset in this path.

For the first time, with this study, we determined the potential benefits and economic feasibility of an integrated OWC at the Port of Genoa. Through the coupling of multi-model nesting, energy analysis and utilising a non-optimised WEC solution, ratios are proposed for which an investment would be feasible. Past studies indicated the possibility of tuning the converter behaviour to local condition, hence scaling its performance is expected to increase the energy production by at least $50 \%[47,56,59]$. An integrated breakwater OWC operates at shallow water areas where surge and depth breaking will be more dominated, and thus simple Froude scaling is not possible.

For the current combination of the resource and off-the-shelf WEC, the following considerations should be taken into account: (i) When CapEx $€ / M W$ cost is less than 2 Million, then almost all capacity scenarios are viable, with the only exception a low installed capacity of $0.5 \mathrm{MW}$. However, when the LCoE is factored in, it is advisable that installation above $1 \mathrm{MW}$ should be considered; (ii) Using metocean conditions to re-scale the OWC size and tune the turbines to match expected climate variations would potentially lead to a better business feasibility for higher CapEx. In this case, all combinations of installed capacities and capital costs are viable, with the only exception again a low installed capacity of $0.5 \mathrm{MW}$. In this approach, the LCoE values are $\approx 50 \%$, staying below $200 € / \mathrm{MWh}$ even at 2.5 Million $€ / \mathrm{MW}$ instances. Usually, first generation ideas with smaller name plate capacity tends to be more expensive; however, in this case "tuning" would increase AEP production and drive electricity driven revenues higher.

A revenue stream for electricity production based on Italian legislation exhibits a clear commitment of the government to advancing novel technologies. An additional revenue stream can be materialised by considering the avoided emissions, from the displacement of fossil fueled electricity. When this is factored in, economic performance of the installation is improved from $45-55 \%$, with avoided emissions having clear positive benefits of the total Italian budgeted Emissions and increased innovation.

Finally, the temporal production overlap potential with other more mature technologies was estimated, between the hours of 6:00 p.m.-8:00 a.m. effectively displacing the need for fossil and/or energy storage. Without OWC optimisation, the integrated installation can provide from 723 ( $\mathrm{min}$ )-939 (max) hours (mean: $785 \mathrm{~h}$ ) of energy production between 6:00 p.m-8:00 p.m, suggesting that the OWC can cover non solar generation worth 30-40 days per year. This, in combination with wind energy, can provide major benefits for renewable electricity, without compromising the grid.

Author Contributions: Conceptualization, G.L. and G.B.; Data curation, F.D.L. and G.B.; Formal analysis, G.L. and F.D.L.; Investigation, G.L. and F.D.L.; Methodology, G.L. and F.D.L.; Resources, G.B.; Writing一original draft, G.L. and F.D.L.; Writing-review and editing, F.D.L. and G.B. All authors have read and agreed to the published version of the manuscript.

Funding: This research received no external funding.

Acknowledgments: The authors would like to thank the editorial team of the Special Issue for considering their submission. The authors would like to thank the reviewers for their valuable comments that improved the manuscript.

Conflicts of Interest: The authors declare no conflict of interest. 


\section{Nomenclature}

$\begin{array}{ll}H_{m 0} & \text { Significant Wave Height } \\ R_{n} & \text { Revenue Stream (electricity } € / \mathrm{kWh} \text { ) } \\ \text { RePower }_{20} & \text { Repowering at year 20 } \\ T_{\text {peak }} & \text { Peak Wave Period } \\ \text { AEP } & \text { Annual Energy Production } \\ \text { bbl } & \text { Barrels of Oil Equivalent } \\ \text { CapEx } & \text { Capital Expenditure } \\ \text { CF } & \text { Capacity Factor } \\ \text { CoV } & \text { Coefficient of Variation } \\ \text { ETS } & \text { Emission Trading System } \\ \text { kW } & \text { Kilo Watts } \\ \text { kWh } & \text { Kilowatt Hours } \\ \text { LCoE } & \text { Levelised Cost of Electricity } \\ \text { m } & \text { Meters } \\ \text { MW } & \text { Mega Watt } \\ \text { MWh } & \text { Megawatt Hours } \\ \text { NECP } & \text { National Energy and Climate Plan } \\ \text { NG } & \text { Natural Gas } \\ \text { OM } & \text { Operation \& Maintenance } \\ \text { OWC } & \text { Oscillating Water Column } \\ \text { PBP } & \text { Payback Period } \\ \text { PPP } & \text { Public-Private Partnerships } \\ \text { PV } & \text { Present Value } \\ \text { SWAN } & \text { Simulating WAves Nearshore } \\ \text { TEUS } & \text { Twenty-Foot Equivalent Unit } \\ \text { Tn } & \text { Tonne } \\ \text { TWh } & \text { Terrawatt Hours } \\ \text { WEC } & \text { Wave Energy Converter } \\ & \end{array}$

\section{References}

1. JRC. The Strategic Energy Technology (SET) Plan; European Commission: Brussels, Belgium, 2017; p. 88. [CrossRef]

2. European Commission. A Clean Planet for all a European Strategic Long-Term Vision for a Prosperous, Modern, Competitive and Climate Neutral Economy; European Commission: Brussels, Belgium, 2018.

3. European Commission. The European Green Deal, Communication from the Commission to the European Parliament, the European Council, the Council, the European Economic and Social Committee and the Committee of the Regions; European Commission: Brussels, Belgium, 2019.

4. Nicholls, R.J.; Cazenave, A. Sea-level rise and its impact on coastal zones. Science 2010, 328, 1517-1520. [CrossRef] [PubMed]

5. Weisse, R.; Bellafiore, D.; Menéndez, M.; Méndez, F.; Nicholls, R.J.; Umgiesser, G.; Willems, P. Changing extreme sea levels along European coasts. Coast. Eng. 2014, 87, 4-14. [CrossRef]

6. Makris, C.; Galiatsatou, P.; Tolika, K.; Anagnostopoulou, C.; Kombiadou, K.; Prinos, P.; Velikou, K.; Kapelonis, Z.; Tragou, E.; Androulidakis, Y.; et al. Climate change effects on the marine characteristics of the Aegean and Ionian Seas. Ocean Dyn. 2016, 66, 1603-1635. [CrossRef]

7. Lionello, P.; Scarascia, L. The relation between climate change in the Mediterranean region and global warming. Reg. Environ. Chang. 2018, 18, 1481-1493. [CrossRef]

8. Leone, G. Mediterranean Quality Status Report; UN Environment Programme; UN: New York, NY, USA, 2017.

9. Wang, H.; Mao, X.; Rutherford, D. Cost and Benefits of Offshore Power at the Power of Shenzhen; International Council on Clean Transportation: Washington, DC, USA, 2017.

10. Samadi, S.; Lechtenbohmer, S.; Schneider, C.; Arnold, K.; Fischedick, M.; Schüwer, D.; Pastowski, A. Decarbonization Pathways for the Industrial Cluster of the Port of Rotterdam; Wuppertal Institute: Wuppertal, Germany, 2016. 
11. Franzitta, V.; Curto, D.; Milone, D.; Trapanese, M. Energy Saving in Public Transport Using Renewable Energy. Sustainability 2017, 9, 106. [CrossRef]

12. European Commission. Eurostat, Italy Country Profile; European Commission: Brussels, Belgium, 2020.

13. IEA. International Energy Agency, Italy Country Profile; IEA: Paris, France, 2020.

14. Integrated National Energy and Climate Plan (Italy); Ministry of Economic Development, Ministry of the Environment and Protection of Natural Resources and the Sea, Ministry of Infrastructure and Transport: Rome, Italy, 2019. Available online: https:/ / ec.europa.eu/energy/sites/ener/files/documents/it_final_ necp_main_en.pdf (accessed on 12 August 2020).

15. Silva, D.; Rusu, E.; Soares, C.G. Evaluation of various technologies for wave energy conversion in the Portuguese nearshore. Energies 2013, 6, 1344-1364. [CrossRef]

16. Rusu, E. Evaluation of the Wave Energy Conversion Efficiency in Various Coastal Environments. Energies 2014, 7, 4002-4018. [CrossRef]

17. Rusu, E.; Onea, F. A review of the technologies for wave energy extraction. Clean Energy 2018, 2, 10-19. [CrossRef]

18. Franzitta, V.; Viola, A.; Trapanese, M. Design of a transverse flux machine for power generation from seawaves. J. Appl. Phys. 2014, 115, 17E712. [CrossRef]

19. Kuo, Y.S.; Chung, C.Y.; Hsiao, S.C.; Wang, Y.K. Hydrodynamic characteristics of Oscillating Water Column caisson breakwaters. Renew. Energy 2017, 103, 439-447. [CrossRef]

20. Vicinanza, D.; Contestabile, P.; Di Lauro, E. Overtopping Breakwater for Wave Energy Conversion: Status and Perspective. In Proceedings of the 12th European Wave and Tidal Energy Conference, Cork, Ireland, 27 August-1 September 2017.

21. Vicinanza, D.; Di Lauro, E.; Contestabile, P.; Gisonni, C.; Lara, J.L.; Losada, I.J. Review of Innovative Harbor Breakwaters for Wave-Energy Conversion. J. Waterw. Port Coast. Ocean Eng. 2019, 145. [CrossRef]

22. PORTOS-Ports Towards Energy Self-Sufficiency. 2020. Available online: https://www.greenport. com/news101/energy-and-technology/ship-to-shore-power-contract-for-port-of-genoa (accessed on 12 August 2020).

23. International Maritime Organization (IMO). Reducing Greenhouse Gas Emissions from Ships; International Maritime Organization: London, UK, 2020.

24. Port Technology, Port of Genoa. 2020. Available online: https://www.porttechnology.org/news/port-ofgenoa/ (accessed on 12 August 2020).

25. Ports of Genoa, The Port Environmental Energy Plan (PEAP). 2020. Available online: https://www. portsofgenoa.com/en/green-port-en/environmental-energy-plan-peap.html (accessed on 12 August 2020).

26. World Ports Sustainable Program, Port of Genoa-Onshore Power Supply to vessels. 2020. Available online: https: / / sustainableworldports.org/project/port-of-genoa-onshore-power-supply-to-vessels / (accessed on 12 August 2020).

27. Agenzia Nazionale per l'attrazione Degli Investimenti e lo Sviluppo d'impresa SpA. 2020. Available online: https:/ / gareappalti.invitalia.it/tendering/tenders/000151-2018/view/detail/1 (accessed on 12 August 2020). (In Italian)

28. Green Port, Ship to Shore Power Contract for the Port of Genoa. 2020. Available online: https://www. greenport.com/news101/energy-and-technology/ship-to-shore-power-contract-for-port-of-genoa (accessed on 12 August 2020).

29. Ibarra-Berastegi, G.; Sáenz, J.; Ulazia, A.; Serras, P.; Esnaola, G.; Garcia-Soto, C. Electricity production, capacity factor, and plant efficiency index at the Mutriku wave farm (2014-2016). Ocean Eng. 2018, 147, 20-29. [CrossRef]

30. Naty, S.; Viviano, A.; Foti, E. Wave Energy Exploitation System Integrated in the Coastal Structure of a Mediterranean Port. Sustainability 2016, 8, 1342. [CrossRef]

31. Rusu, L.; Onea, F. The performance of some state-of-the-art wave energy converters in locations with the worldwide highest wave power. Renew. Sustain. Energy Rev. 2016, 75, 1348-1362. [CrossRef]

32. Lavidas, G.; Venugopal, V. A 35 year high-resolution wave atlas for nearshore energy production and economics at the Aegean Sea. Renew. Energy 2017, 103, 401-417. [CrossRef]

33. Mentaschi, L.; Besio, G.; Cassola, F.; Mazzino, A. Developing and validating a forecast/hindcast system for the Mediterranean Sea. J. Coast. Res. 2013, 65, 1551-1556. [CrossRef] 
34. Mentaschi, L.; Besio, G.; Cassola, F.; Mazzino, A. Performance evaluation of Wavewatch III in the Mediterranean Sea. Ocean Model. 2015, 90, 82-94. [CrossRef]

35. SWAN User Manual Cycle III Version 41.01; Technical Report; Delft University of Technology Faculty of Civil Engineering and Geosciences Environmental Fluid Mechanics Section: Delft, The Netherlands, 2020.

36. Booij, N.; Holthuijsen, L.; Ris, R. The "SWAN" wave model for shallow water. In Proceedings of the 25th International Conference on Coastal Engineering, Orlando, FL, USA, 2-6 September 1996.

37. Amarouche, K.; Akpınar, A.; Çakmak, R.E.; Houma, F.; Bachari, N.E.I. Assessment of storm events along the Algiers coast and their potential impacts. Ocean Eng. 2020, 210, 107432. [CrossRef]

38. Camus, P.; Mendez, F.J.; Medina, R. A hybrid efficient method to downscale wave climate to coastal areas. Coast. Eng. 2011, 58, 851-862. [CrossRef]

39. Mucerino, L.; Albarella, M.; Carpi, L.; Besio, G.; Benedetti, A.; Corradi, N.; Firpo, M.; Ferrari, M. Coastal exposure assessment on Bonassola bay. Ocean Coast. Manag. 2019, 167, 20-31. [CrossRef]

40. Saviano, S.; De Leo, F.; Besio, G.; Zambianchi, E.; Uttieri, M. HF Radar Measurements of Surface Waves in the Gulf of Naples (Southeastern Tyrrhenian Sea): Comparison With Hindcast Results at Different Scales. Front. Mar. Sci. 2020, 7, 492. [CrossRef]

41. Contestabile, P.; Di Lauro, E.; Buccino, M.; Vicinanza, D. Economic Assessment of Overtopping BReakwater for Energy Conversion (OBREC): A Case Study in Western Australia. Sustainability 2016, 9, 51. [CrossRef]

42. Disciplinare Di Gara Telematica, Procedura Per L'affidamento Del Servizio Di Progettazione Di Fattibilità Tecnica Ed Economica Afferente All'intervento Di Realizzazione Della Nuova Diga Foranea Del Porto Di Genova-Ambito Bacino Di Sampierdarena; Invitalia: Rome, Italy, 2020. (In Italian)

43. Babarit, A.; Hals, J.; Muliawan, M.; Kurniawan, A.; Moan, T.; Krokstad, J. Numerical benchmarking study of a selection of wave energy converters. Renew. Energy 2012, 41, 44-63. [CrossRef]

44. Blok, K.; Nieuwlaar, E. Introduction to Energy Analysis, 2nd ed.; Routledge: London, UK, 2017.

45. De Andres, A.; Medina-Lopez, E.; Crooks, D.; Roberts, O.; Jeffrey, H. On the reversed LCOE calculation: Design constraints for wave energy commercialization. Int. J. Mar. Energy 2017, 18, 88-108. [CrossRef]

46. Rusu, E.; Onea, F. Estimation of the wave energy conversion efficiency in the Atlantic Ocean close to the European islands. Renew. Energy 2016, 85, 687-703. [CrossRef]

47. Bozzi, S.; Besio, G.; Passoni, G. Wave power technologies for the Mediterranean offshore: Scaling and performance analysis. Coast. Eng. 2018, 136, 130-146. [CrossRef]

48. Lavidas, G. Selection index for Wave Energy Deployments (SIWED): A near-deterministic index for wave energy converters. Energy 2020, 196, 117131. [CrossRef]

49. Sannino, G.; Pisacane, G. Ocean Energy Exploitation in Italy: Ongoing RED Activities. Technical Report September; Italian National Agency for New Technologies, Energy and Sustainable Economic Development: Guipuzcoa, Spain, 2017.

50. Lavidas, G. Developments of energy in EU-unlocking the wave energy potential. Int. J. Sustain. Energy 2018, 38, 208-226. [CrossRef]

51. Markets Insider, Commodities, $\mathrm{CO}_{2}$ European Emission Allowance in Euro. 2020. Available online: https: //markets.businessinsider.com/commodities/co2-european-emission-allowances (accessed on 12 August 2020).

52. De Leo, F.; De Leo, A.; Besio, G.; Briganti, R. Detection and quantification of trends in time series of significant wave heights: An application in the Mediterranean Sea. Ocean Eng. 2020, 202, 107155. [CrossRef]

53. De Leo, F.; Besio, G.; Mentaschi, L. Trends and variability of sea waves under RCP8.5 emission scenario in the Mediterranean Sea. Ocean Dyn. Under Review.

54. Aldersey-Williams, J.; Rubert, T. Levelised cost of energy-A theoretical justification and critical assessment. Energy Policy 2019, 124, 169-179. [CrossRef]

55. Lazard. LAZARD's Levelized Cost of Storage Analysis-Version 4.0. 2020. Available online: https: / / www.lazard.com/media/450774/lazards-levelized-cost-of-storage-version-40-vfinal.pdf (accessed on 12 August 2020).

56. Simonetti, I.; Cappietti, L.; El Safti, H.; Oumeraci, H. Numerical Modelling of Fixed Oscillating Water Column Wave Energy Conversion Devices: Toward Geometry Hydraulic Optimization. In International Conference on Offshore Mechanics and Arctic Engineering; American Society of Mechanical Engineers: New York, NY, USA, 2015. [CrossRef] 
57. Simonetti, I.; Cappietti, L.; Elsafti, H.; Oumeraci, H. Evaluation of air compressibility effects on the performance of fixed OWC wave energy converters using CFD modelling. Renew. Energy 2018, 119, 741-753. [CrossRef]

58. Friedrich, D.; Lavidas, G. Evaluation of the effect of flexible demand and wave energy converters on the design of Hybrid Energy Systems. Renew. Power Gener. 2017, 12. [CrossRef]

59. Luppa, C.; Cavallaro, L.; Foti, E.; Vicinanza, D. Potential wave energy production by different wave energy converters around Sicily. J. Renew. Sustain. Energy 2015, 7, 061701. [CrossRef]

(C) 2020 by the authors. Licensee MDPI, Basel, Switzerland. This article is an open access article distributed under the terms and conditions of the Creative Commons Attribution (CC BY) license (http:/ / creativecommons.org/licenses/by/4.0/). 